\title{
Analysis of The Empowerment Policy of The Ethnic Community in Building Social Harmony (Case Study of Lampung Transmigrant)
}

\author{
Tauhidi $^{1}$, Fauzi Nurdin ${ }^{2}$, Bambang Budiwiranto $^{3}$, Fitri Yanti $^{4}$ \\ \{tauhidiismaik@gmail.com¹, a.fauzie.nurdin@gmail.com², bambangbudiwiranto@ radenintan.ac.id ${ }^{3}$, \\ fitriyanti@radenintan.ac.id $\left.{ }^{4}\right\}$ \\ Student PMI Doctoral Program of UIN Raden Intan Lampung, Indonesia ${ }^{1}$, Lecture UIN Raden Intan \\ Lampung, Indonesia ${ }^{2}$, Lecture UIN Raden Intan Lampung, Indonesia ${ }^{3}$, Lecture UIN Raden Intan \\ Lampung, Indonesia ${ }^{4}$
}

\begin{abstract}
The research aims to conduct policy analysis on empowering ethnic communities in building social harmony - the research conducted in the transmigrant area of Lampung. The research method used is qualitative research. Data collection techniques were carried out through field observations and documentary studies. The findings reveal that government policies have an essential role to play in building the empowerment of ethnic communities in creating a much better social harmony. However, in the field, this has encountered various obstacles and challenges. Social harmonization constrains by anti-social behavior. Debates in different social communities and the lack of guidance and socialization on the empowerment of ethnic communities are practical and efficient. However, the social structure of Lampung transmigrants, which was built based on the principles of cooperation, openness, tolerance, and healthy competence, led to much better empowerment of ethnic communities. The implication of this research is to provide input on the policy direction of stakeholders in formulating strategies for empowering ethnic communities to build social harmony, avoid conflicts between ethnic groups, and create social welfare in Indonesia.
\end{abstract}

Keywords: Policy, Empowerment, Ethnicity, Social Harmony.

\section{Introduction}

The empowerment of ethnic communities is increasing globally. The aim is to build social harmony in society to live side by side without any socio-economic conflicts. In this case, of course, government policy plays an important role. Developing creativity and promoting social harmony is one way that can done [1]. Social harmony campaigns can reflect the social qualities of a region [2]. In other words, to find out the social quality in an area can be seen from the behavior of the community in implementing ethnic community empowerment policies.

The development of community empowerment studies occurs in line with social, economic, religious, government, political, and cultural development. This dynamic has led to many changes in the structure of agriculture, plantations, trade, and industry. Also changes in the function of social institutions, transmigration, economic behavior, politics, and religion among more rational citizens. By encouraging social harmony through the empowerment of ethnic communities, these government policies can increase social resilience. Unfortunately, some cities are sometimes more difficult to activate. It is the reason why it is essential to 
conduct further research. Previous studies have shown that stakeholder support can create healthy ethnic communities [3]. It further explained that if a country wants an ethnic community that can build social harmony, then the intervention must be designed together with all citizens of society. The social dynamics that occur in society indicate by the insight into the positive role of social harmony on various problems of social life and the dynamic plurality of local cultures. Psychologically, the balance between groups indicates the ability to absorb information and a culture that develops rapidly in line with science, technology, and communication [4].

In Indonesia, policies related to the empowerment of ethnic communities build social harmony based on the Marine Policy of the Minister of Religion and the Minister of Home Affairs Number 9 and 8 of 2006. It was carried out through a forum for empowering religious harmony. Recent studies reveal that the success of policies is highly dependent on the role of the government in granting authority to the management of the forum to take action as a management team for delivering information on policies formulated by the central/regional government [5].

Policies for empowering social, religious, local cultural communities and regional development can be more effective if a well-integrated social system is homogeneous. Although it also needs to be observed, the diversity and dynamics of the community in the plurality local cultures. There are complexities of power and adverse circumstances, each of which is central to understanding and leading to a more empowered and useful society. The idea and actualization of community empowerment are involved, both in itself and in the process of interaction with communities outside it, which in its dynamics often occurs cooperation, competition, and conflict in various social, political, and economic fields. Conceptual community empowerment policies have a variety of strategies to achieve the goals and objectives of disadvantaged groups [6]. These strategies can broadly classify policies and planning, social action, economy, politics, education, and self-awareness in various social communities.

Some of these historical and empirical arguments indicate how it must admit that no single approach can provide a complete and comprehensive explanation of the existing social harmonization because there is always a mutual relationship between concepts, theories, and policies with one another. Social harmony in social order can identify through ties to self-help groups, and the relationship between members of the self-help group and the wider community [7][8]. Given that each research approach used to uncover and explain scientific truth has its basis for arguments with the level of truth determined by how closely the views are built based on social, economic, cultural, and regional development problems observed and studied scientifically.

\section{Methods}

This research is a qualitative descriptive study conducted in transmigration areas, especially in Bagelen Village, Pesawaran District, Lampung Province, as the selected locus. After further investigation, the chosen objects were the Javanese Muslim Ethnic Community. And the Muslim Lampung Ethnic Community in the transmigrant area, which was active in carrying out harmonious community development activities in the first transmigration area during the colonial period in Bagelen village, Gedong Tataan sub-district, Pesawaran Regency. Therefore this research was deliberately carried out on the transmigrant community 
of the Javanese Muslim and Muslim Lampung ethnic groups who could empower to build social harmony among the Bagelen transmigrants in Lampung. Strictly speaking, this research focuses on government policies and their activities in building social peace.

Data collection techniques carried out by field observations, interviews, and documentation studies; so that the real problems that occur can be studied, compared, and analyzed scientifically. Interviews can work with several community members. Who understood and knew the history of colonization in its early days, religious leaders, traditional leaders, sub-district government officials, and village officials. Then the information was cross-checked to test the validity and accuracy of field data. Meanwhile, documents based on records of past events related to the focus and sub-focus of research can trace from the presence of writings, pictures, or monumental works of a particular person, family, group, and social community.

\section{Result and Discussion}

The initial description of these findings base on the results of researching theories that implement correctly to become creative learning and training so that they stimulate a positive, informed, innovative and reflective approach to a society based on shared awareness to build the future. Based on the theory of community empowerment, which has been formulated by experts,

"Empowerment is a word that has been overused and is in danger of losing its substantive meaning. It is the center of community work ideas, and many community workers will choose to define their role in terms of an empowerment process. However, a simple work definition will suffice, namely: Empowerment aims to increase the charge of disadvantaged (the disadvantaged) [9]."

Based on this theory, it can conceptually clarify the existence of a pluralist perspective of empowerment. Empowerment through policy and planning achieved by developing or changing structures and institutions to gain fairer access to resources or services and opportunities to participate in community life. Positive affirmative action or discrimination policies recognize the existence of disadvantaged groups (sometimes expressed specifically in structural terms) and seek to remedy this by 'changing the rules' to benefit the disadvantaged group [9].

In the transmigrant area of Lampung, in Bagelen village, Pesawaran District, Lampung Province, there have been many events of changing social structures and empowering social institutions. The Javanese Muslim and Lampung Muslim Ethnic Communities in transmigrant areas are quite active in carrying out harmonious community development activities in the transmigration areas. The first was during the colonial period in Bagelen Village, Gedong Tataan sub-district, Pesawaran Regency. More focus can see the empowerment of ethnic communities to increase resources, access, and opportunities for the community. Interviews conducted with several traditional adat leaders and religious leaders in the transmigrant area of Lampung expressed the same view of efforts to build social harmony, namely by providing sufficient and safe resources to the people,

"The transmigrant community tries to avoid social conflicts. The city established a community forum as a forum for community aspirations. Regardless of ethnicity, people voluntarily cooperate, tolerate, and exchange ideas in creating mutual security and comfort. People live side by side and try to make a healthy competition in business." 
According to Jim Ife and Frank Tesoriero (2008), empowerment through social and political action emphasizes the importance of struggle and political change in increasing adequate power. How this is applied depends on our understanding of power in the political process (pluralist, elite, structural, or post-structural). But he emphasized an activist approach and sought to enable people to increase their power through direct (and often collective) action, or by equipping them to be more effective in the political arena [9].

In the process of building towards social harmony, the Javanese Muslim ethnic community and the Muslim Lampung ethnic group experience the process of mixing two or more cultures that meet. And influence each other or the operation of the entry of foreign cultural influences on society, some selectively absorb few or many elements of the foreign culture. And some try to resist this influence or the result of a cultural or linguistic encounter between members of a bilingual society, characterized by borrowing or bilingualism.

In the transmigrant area of Lampung, everything arranged like the Javanese village pattern, including the government structure with the kamituwo, lurah, and assistant wedana, which was different from the surrounding government structures. In connection with the village government system, which has a community service function and as a permanent residence for Javanese people, in the hinterland, it is a jurisdiction that is also the center of the lowest regional level government. Administratively, the village is directly under the control of the sub-district government and consists of dukuh-dukuh. A dukuh head chairs each part of the village [10].

The empowerment of the Lampung transmigrant community is dynamically in line with development developments, as indicated in the existence of the product in all fields. However, these government policies have not succeeded in alleviating poverty and the increasing number of unemployed workers, difficulties in obtaining job opportunities, and high basic needs and living costs. Development claimed to be the government's authority so that people must submit and obey the implementation process, which is planned by the government itself, which tends to without involving the aspirations of the community. "Mobilization to participate in development is the obligation of a society as a form of obedience and devotion to the state and not based on existing awareness in society. As a result, development becomes a centralized and biased center [11]."

Empowerment of communities of different ethnicities and adherents of religion can be carried out through human resource development in accordance with Islamic religious values [12]. The empowerment of the Islamic community is an empirical model for developing individual and collective behavior, emphasizing solving various concrete problems, including the management of conflict resolution faced by local communities.

Based on Figure 1, it can be understood that empowering as a basis for social movement towards a harmonious society, of course, needs to teach people not to be arrogant, proud of themselves, commit zolim; practice in order to be able to master and control feelings of envy, jealousy and jealousy of others. This means that religious empowerment (ruhaniyah) for social groups, communities of various ethnicities, as well as every family and individual of course must be based on faith, taqwa, morality and high and consistent religious moral values. It is interesting to study expert testimonials. 


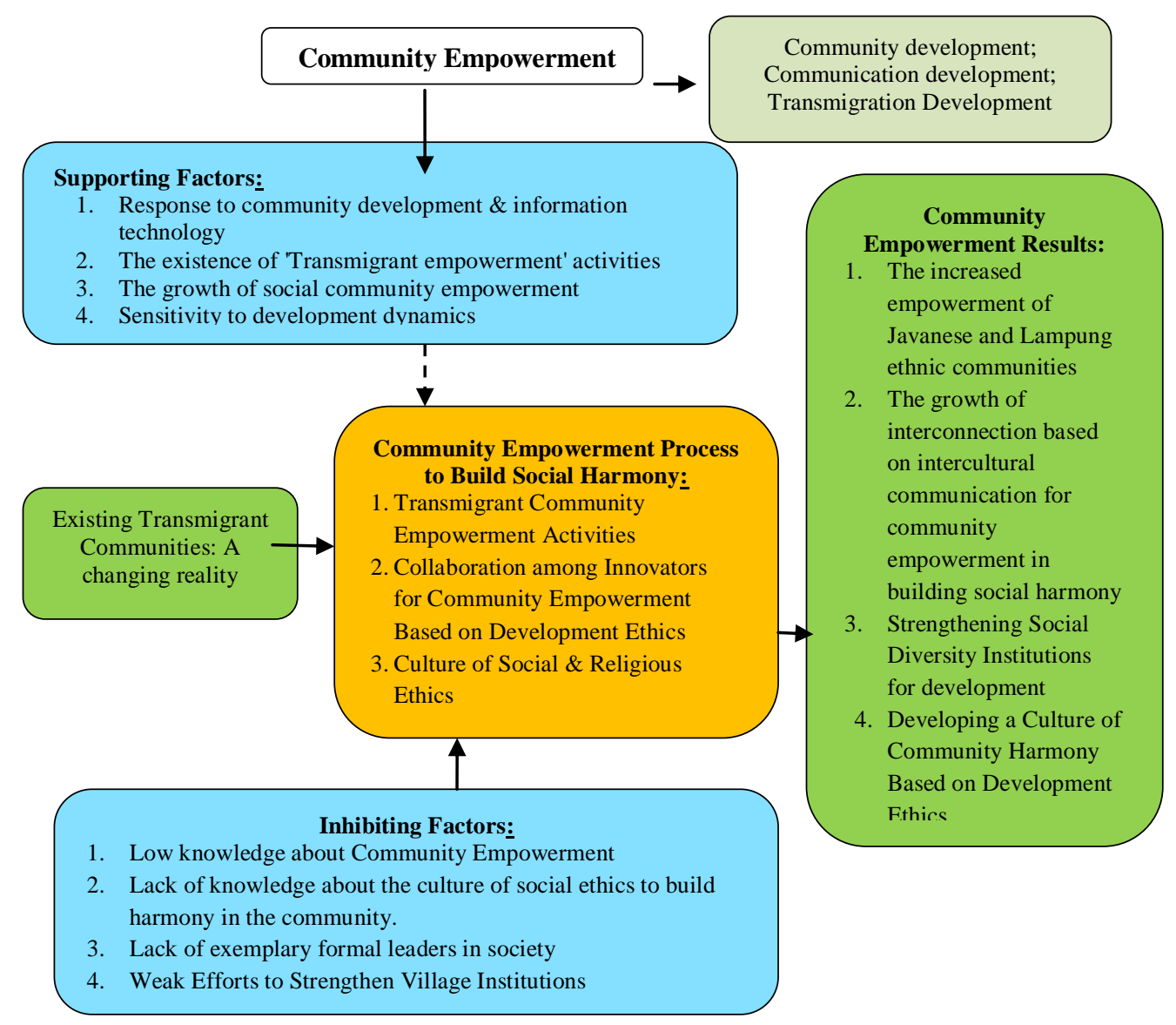

Fig. 1. Empowerment of Muslim Javanese and Muslim Lampung ethnic communities in building social harmony

The interconnection of social community empowerment can apply Community Development theory as a normative concept and efforts to improve and change the living conditions of each individual (which focuses on the social, religious, and local cultural community. Including the Javanese Muslim and Lampung Muslim ethnic communities, which are diverse and dynamic. In various districts and cities in the province of Lampung, which aims to change the pattern of orientation, attitude, positive moral behavior in the development process. For this reason, a community development strategy is implemented based on the principle of good cooperation from government elements, community organizations, religious institutions, and local non-governmental organizations, especially in underdeveloped villages. On that basis, the framework in this study refers to the model cited and modified from community empowerment researchers, [13] which is described as follows 


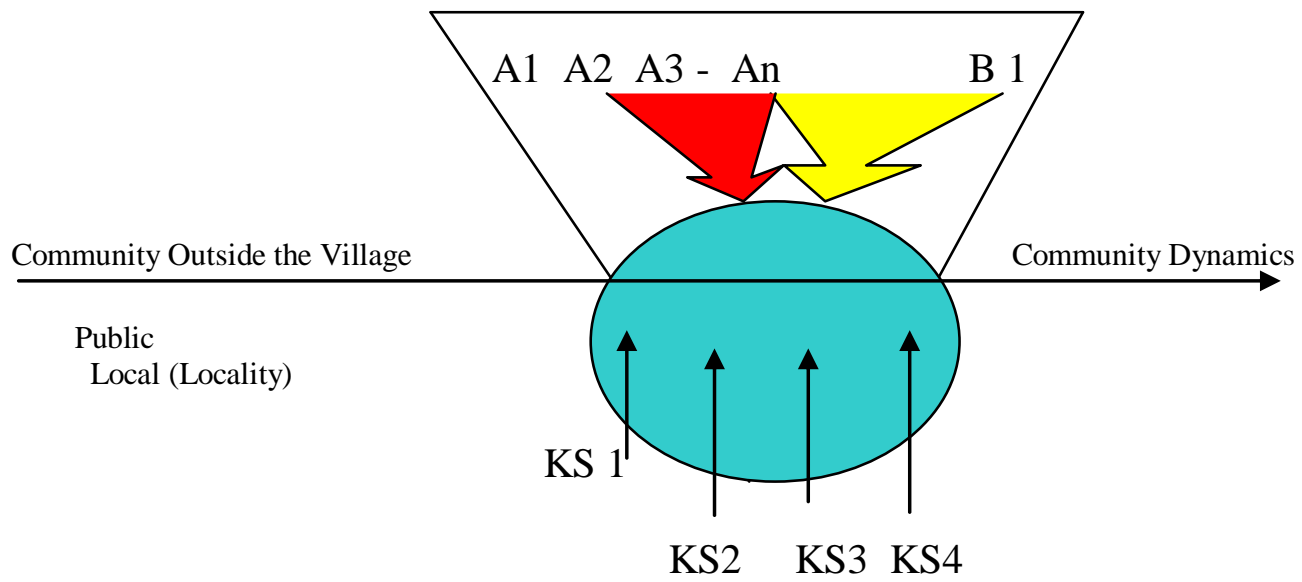

Information:

Fig. 2. Local Community Development Model

$\mathrm{A} 1, \mathrm{~A} 2, \mathrm{~A} 3-\mathrm{An} \quad=$ Government program

$\mathrm{B} 1 \quad$ = Non-government program

KS1-KS4 = Non-governmental organizations

In the context of implementing governance in the transmigrant area of Lampung, it certainly expected that all elements of society, together with government officials in the regions, can increase their capabilities, both extractive and regulative. Formulating various signs of participatory and proactive community development towards the needs and opportunities of regional development is a challenge in itself, especially about national and global competition. For that, it means that the development of local potential can also be done through innovation to increase the productivity of reformists, capable and willing to take risks in their implementation. Likewise, those who can develop cooperation or build networks. Both within (organization consolidation with all staff and workers) and outside the region and even abroad.

The empowerment process can carry out with an intervention model such as local community development, social planning and policy, and social action. The three models of intervention are: The process of community empowerment can carry out through consensus approaches such as local community development (locality dev), "compliance" such as social planning and policy approaches (social planning/policy), or through "conflict" approaches such as social action [14]. Another study states that in formulating new policies, it is necessary to consider the following, namely: 1) the government must be fair and sincere in public communication; 2) Stakeholders support and respect each other with integrity and dedication; 3 ) dedication to work and community by helping each other; and 4) creative and tolerance among religious communities [6].

Empowerment needs to be formulated and must respond to changes in society to anticipate various problems that will arise in implementing development programs in the field. Is means that implementing community empowerment in different communities requires a participatory approach and building an equal relationship between the community and program organizers. Mean,

"Community development based on local culture can function as a process aimed at creating social and economic progress for the community through the active participation and initiative of community members themselves. Community members are seen not as a 
problematic client system, but as a unique and potential society; it's just that this potential has not fully developed [14]."

Next, the study of community empowerment begins with understanding the meaning of "community" in a sociological perspective differentiated from society (in English), the Indonesian translation means "society." In this case, community development experts formulate,

"Community is a social unit or unit organized into groups with a common interest, both functional and territorial. The term community can translate as a local community. The community within certain boundaries can refer to residents of a hamlet (dukuh or kampung), village, city, tribe, or nation. If members of a group, whether large or small, live together to feel that the group can fulfill the main life interests, then the group is called a community [15]."

A community has various typologies and characteristics in its respective locality. Organizations that have permanent and permanent residence tend to have strong solidarity ties due to the unity of their home. It is interesting to look at the opinion of this expert, which states:

For a group of community members, development claimed to be the government's authority so that people must submit and obey the implementation process planned by the government itself, which tends to without involving the aspirations of the community. Such community development conditions indicate there is

"Mobilization to participate in development is the obligation of a society as a form of obedience and devotion to the state and not based on existing awareness in the community. As a result, development has become a centralized and biased center [16]."

It means. Clearly, this context emphasizes that community empowerment as a community-focused development approach increasing needed in the framework of developing a more dignified and democratic society in the future. Indeed, so far, the role of the state has been prominent in implementing a centralized and top-down development strategy and approach. A further implication is that patterns that emphasize uniformity dominated.

Overall, the findings indicate that social harmony in the transmigrant area of Lampung built on acculturation between religion and culture. Although sometimes there are differences of opinion in the ethnic community, these problems do not seem to trigger conflict. There is healthy mediation, a high sense of tolerance, cooperation, and implementing the norms that apply in society to carry out a social and economic life. This study is in line with research conducted by Stein (2013), which revealed that useful community mediation has a positive impact on social harmony [17]. The policies developed by the government to campaign for social harmony appear to be quite useful. In the future, government policies expect to bridge the gaps between various ethnic groups in Indonesia to create national peace and security.

\section{Conclusion}

A more interconnected approach in a cross-scientific manner, of course, hoped that the root causes of social and religious conflicts can identify, which can then be watched out for and attempted to prevent so that such problems can adequately manage to build social harmony. In the future, it will not happen again and develop widely so that it disrupts national disintegration. However, making social peace appears to be that the government does not have adequate instruments to pay special attention to social conflict issues so far. The handling seems sporadic, then late, disorganized, and even tends to drag on. 
The benefits of the research expected to be useful for the development of science, both theoretically and conceptually in the field of Islamic community development, which focuses on (1) Empowerment of Javanese Muslim and Lampung Muslim ethnic communities to build social harmony in a plurality of local cultures. (2) The concept of empowering Javanese Muslim and Muslim ethnic Lampung communities can create social harmony in most local cultures, especially among Bagelen transmigrants.

\section{References}

[1] K. I. P. Vong, "Developing creativity and promoting social harmony: The relationship between government, school and parents' perceptions of children's creativity in Macao-SAR in China," Early Years, vol. 28, no. 2, pp. 149-158, 2008.

[2] C.-M. R. Chau and W. S. Yu, "Social quality and the social harmony campaign in Hong Kong," Dev. Soc., vol. 38, no. 2, pp. 277-295, 2009.

[3] M. Markantoni, A. Steiner, J. E. Meador, and J. Farmer, "Do community empowerment and enabling state policies work in practice? Insights from a community development intervention in rural Scotland," Geoforum, vol. 97, no. May, pp. 142-154, 2018.

[4] N. S. Kteily and K. J. McClanahan, "Incorporating insights about intergroup power and dominance to help increase harmony and equality between groups in conflict," Curr. Opin. Psychol., vol. 33, pp. 80-85, 2020.

[5] M. T. Tanggung, S. Suwitri, E. Larasati, and R. Gonibala, "Implementation of Joint Regulation Policies of the Minister of Religion and Minister of Home Affairs Number 9 and 8 of 2006 through Empowerment of Religious Harmony Forums in Manado City,” vol. 2, no. 4, pp. 95 $110,2020$.

[6] S. S. M. Ho and R. S. Y. Chan, "Social harmony in Hong Kong: Level, determinants and policy implications," Soc. Indic. Res., vol. 91, no. 1, pp. 37-58, 2009.

[7] G. Knowles and B. Luke, "The impact of microfinance programs and self-help groups on social order in poor communities," Third Sect. Rev., vol. 24, no. 2, pp. 35-56, 2018.

[8] L. Tomba, "Of quality, harmony, and community: Civilization and the middle class in Urban China," Positions, vol. 17, no. 3, pp. 591-616, 2009.

[9] J. Ife and F. Tesoriero, Community Development: Alternatif Pengembangan Masyarakat di Era Globalisasi. Yogyakarta: Pustaka Pelajar. Yogyakarta: Pustaka Pelajar, 2008.

[10] Kodiran, Kodiran, Kebudayaan Jawa , dalam Koentjaraningrat, Manusia dan Kebudayaan di Indonesia, Jakarta, Penerbit Djambatan, cet.20, 2004. Jakarta: Djambatan, 2004.

[11] I. Setiawan, Agribisnis kreatif: pilar wirausaha masa depan, kekuatan dunia baru menuju kemakmuran hijau. Cimanggis, Depok: Swadaya Grup, 2012.

[12] M. Thoyib, "Pesantren and Contemporary Multicultural Islamic Education: Empowering plurality toward realizing social harmony and peace in Indonesia," in Advances in Social Science, Education and Humanities Research, 2019, vol. 307, no. SoRes 2018, pp. 543-551.

[13] A. F. Nurdin, Pemberdayaan Dai Dalam Masyarakat Lokal (Studi Kasus di Dua Desa Tertinggal Kabupaten Lampung Selatan). yogyakarta: Gama Media, 2009.

[14] Alfitri, Community Development: Teori dan Aplikasi. Jakarta: Pustaka Pelajar, 2011.

[15] F. Tonny Nasdian, Pengembangan Masyarakat. Jakarta: Yayasan Pustaka Obor Indonesia, 2014.

[16] "Susetiawan, 'Pemberdayaan Masyarakat antara Ide dan Komoditi Baru Untuk Perubahan Sosial', dalam Suparjan dan Hempri Suyatno, Pengembangan Masyarakat dari Pembangunan Sampai Pemberdayaan, (Yogyakarta: Aditya Media, 2003), h. xii-xv,” p. 2003, 2003.

[17] D. Stein, Community Mediation And Social Harmony In Nepal, no. May. London: Department, LSE, Houghton Street, 2013. 